\title{
Epifaunal community composition and nutrient addition alter sediment organic matter composition in a natural eelgrass Zostera marina bed: a field experiment
}

\author{
Amanda C. Spivak ${ }^{1,2, *}$, Elizabeth A. Canuel ${ }^{1}$, J. Emmett Duffy ${ }^{1}$, James G. Douglass ${ }^{1}$, \\ J. Paul Richardson ${ }^{1}$ \\ ${ }^{1}$ Virginia Institute of Marine Science, College of William and Mary, PO Box 1346, Gloucester Point, \\ Virginia 23062-1346, USA \\ ${ }^{2}$ Present address: Miami University, Zoology Department, Oxford, Ohio 45056, USA
}

\begin{abstract}
Eutrophication and fishing are common perturbations in aquatic ecosystems that have pervasive effects on community structure, including species diversity and abundance. While sediment biogeochemical processes probably respond to these stressors, the linkages to ecosystem functioning remain poorly understood. To explore these linkages, we experimentally manipulated water column nutrient levels and food web composition (i.e. predator and grazer presence and absence) in a factorial design using field enclosures situated in a natural eelgrass Zostera marina bed. After $28 \mathrm{~d}$, we quantified sediment organic matter (SOM) abundance and composition using measures of total organic carbon and nitrogen as well as fatty acid (FA) biomarkers. Nutrient enrichment led to a rapid increase of epiphytes and a decline in $Z$. marina biomass. Responding to the available algae, grazers reduced epiphytes and the abundance of microalgal FAs in the sediment. Predators reduced $Z$. marina abundance and possibly its ability to trap particulate organic matter $(\mathrm{OM})$, leading to lower sediment organic carbon content and total FA abundance. There was evidence of a trophic cascade as FA contributions to sediments from epiphytes and diatoms were higher in treatments with both grazers and predators than in treatments with grazers only. Predators increased contributions of labile diatom-derived OM, which probably resulted in higher proportions of bacterial FA. Interactions between nutrient additions and food web composition indicated that SOM responses were complex and not predictable from single variables. Changes in SOM composition, combined with a rapid heterotrophic bacterial response, suggest that resource levels and aboveground community structure are important to sediment biogeochemistry in natural seagrass systems.
\end{abstract}

KEY WORDS: KEY WORDS: Epifaunal $\cdot$ Nutrient addition $\cdot$ Sediment organic matter $\cdot$ Seagrass · Zostera marina $\cdot$ Fatty acids

\section{INTRODUCTION}

Bottom-up (i.e. resource availability) and top-down (i.e. food chain length) controls act in concert to affect biomass accumulation across trophic levels as well as in biogeochemical cycles (Chase et al. 2000, Hillebrand 2002, Hughes et al. 2004, Burkepile \& Hay
2006). In seagrass systems, for example, elevated resource levels and changes in top predator abundance may increase plant biomass and the delivery of plant-derived organic matter (OM) to the sediments (Canuel et al. 2007, Spivak et al. 2007). The quality and rate of OM deposition, in turn, can have large effects on OM decomposition and carbon burial in sediments 
(Hansen \& Blackburn 1992, Cebrian \& Duarte 2001). Consequently, resource availability and community composition may synergistically alter sediment biogeochemistry and ecosystem functioning. Here, we experimentally tested how food web structure and nutrient enrichment alter sediment organic matter (SOM) abundance and quality in a natural eelgrass Zostera marina ecosystem. A goal of this field experiment was to determine whether linkages among food web composition, resource levels and SOM identified in previous mesocosm experiments (Canuel et al. 2007, Spivak et al. 2007) can be observed in the more complex natural environment.

In vegetated coastal habitats, photosynthetic carbon is channeled through grazers, exported to neighboring ecosystems, or buried in the sediments (Pergent et al. 1994, Duarte \& Cebrian 1996, Cebrian \& Duarte 2001, Duarte et al. 2005). Small invertebrate grazers mainly consume nutrient-rich algae and epiphytes, leaving senesced seagrass blades and rhizomes as the main source of buried OM (Pergent et al. 1994, Duarte \& Cebrian 1996, Cebrian 1999, Cebrian \& Duarte 2001). Eutrophication may alter the proportion of algal and epiphytic carbon that is exported or buried by stimulating higher rates of production, changing the composition of primary producer assemblages and/or altering the effectiveness of grazers in cropping production (Cloern 2001, Duarte 2002). Deposition of higher quality OM derived from labile algae can stimulate bacterial decomposition (Hansen \& Blackburn 1992, Boschker \& Cappenberg 1998) and, hence, the depletion of oxygen and lower redox conditions in the sediments. As anoxic conditions develop, sulfate reduction may become a dominant pathway for OM decomposition. Thus, eutrophication may dually effect seagrass by increasing algal-mediated shading (Cloern 2001, Duarte 2002, Orth et al. 2006) and sediment dissolved sulfide concentrations (Hemminga 1998, Calleja et al. 2007, Perez et al. 2007).

The symptoms of eutrophication may be diminished or amplified by food web composition and structure (Carpenter et al. 1985, Pace et al. 1999). In a 2-level food web, strong grazing controls can reduce the negative effects of nutrient loading by channeling algal production into animal biomass (Hughes et al. 2004, Burkepile \& Hay 2006, Heck \& Valentine 2007). Further, grazer species identity and feeding preferences can strongly influence the composition of the primary producer community (Duffy \& Hay 2000, Duffy 2003). In a 3-level food web, predators can exaggerate the effects of nutrient enrichment by inhibiting grazers and releasing algae and epiphytes from grazing pressures via a trophic cascade (Oksanen et al. 1981, Carpenter et al. 1985, Forrester et al. 1999, Pace et al. 1999). Therefore, the effects of nutrient enrichment in seagrass beds may be influenced by trophic structure and community composition.

Despite potentially strong bottom-up and top-down effects on OM deposition and the importance of SOM quality to sediment biogeochemistry (Duffy et al. 2003, Canuel et al. 2007, Spivak et al. 2007), the synergistic effects of nutrient enrichment and community composition on SOM are poorly understood. This is probably due to the difficulty in identifying and manipulating links between above-ground ecology and sediment processes under realistic conditions. Lipid biomarkers are a functional proxy for linking OM to its potential sources (Lechevalier \& Lechevalier 1988, Harvey 1994, Canuel et al. 1995, Canuel \& Martens 1996), since these compounds are reliably produced by specific groups of organisms (Napolitano 1998, Dalsgaard et al. 2003). Diagnostic biomarkers often have site-specific methyl groups, double bonds or cyclic side chains useful for tracing sources of OM (Napolitano 1998, Dalsgaard et al. 2003). Some groups of bacteria, for example, synthesize iso- and anteiso-branched fatty acids while microalgae contain highly unsaturated long chain fatty acids (Harwood \& Russell 1984, Taylor \& Parkes 1985, Volkman et al. 1998). In addition, lipid biomarkers are sufficiently resistant to degradation to be preserved in sediments, allowing for the identification of OM that has been deposited on ecological and historical timescales (Meyers 1997, Zimmerman \& Canuel 2002). Here, we used fatty acids (FAs), a class of lipid biomarkers with high source fidelity and a range of chemical reactivity (Canuel et al. 1995, Canuel \& Martens 1996), to experimentally quantify links between the aboveground community and SOM content and composition.

To assess the effects of changing resource availability and food web structure on carbon fate and storage in a natural seagrass bed, we conducted an experimental manipulation of bottom-up forcing (water column nutrient addition) and food web structure (grazer and predator presence) and measured their interacting effects on SOM composition. Specifically, we built on previous mesocosm studies examining the effects of community diversity (Canuel et al. 2007) and light levels (Spivak et al. 2007) on SOM composition to test several hypotheses in this field experiment. First, we predicted that nutrient enrichment would increase algal biomass and the deposition of algal-derived OM to the sediments. The increased lability of SOM would, in turn, stimulate sediment heterotrophic bacterial activity and the accumulation of bacterial FAs. Second, algae would indirectly decrease Zostera marina abundance by increasing competition for light and nutrients. The presence of a grazer community would reduce algal accumulation and the abundance of their characteristic FAs in the sediment and would increase 
Z. marina. Finally, the presence of predators would result in a trophic cascade in which grazer abundance was reduced and algal biomass and OM contributions to the sediments were increased.

\section{MATERIALS AND METHODS}

Experimental design. This field experiment examined the main and interactive effects of food web structure (i.e. grazer and predator presence) and water column nutrient addition on SOM content and composition in a natural eelgrass bed. Grazer treatments had 2 levels, either zero grazers or an assemblage of 3 species (an amphipod, Gammarus mucronatus, and 2 isopods, Erichsonella attenuata and Idotea balthica). Predator presence was manipulated by exposing parallel sets of these 2 grazer treatments to a generalist predator, the blue crab Callinectes sapidus. There were 8 treatments, each replicated 5 times for a total of 40 experimental field cages. Nutrient addition was controlled through fertilizer additions (Osmocote ${ }^{\mathrm{TM}}$ ) to half of the cages. To control for caging effects, we established no-cage control plots that only received nutrient treatments, since it was impractical to maintain grazer and predator treatments without cages. There were 2 no-cage treatments (with nutrients versus without nutrients), each replicated 5 times for a total of 10 no-cage control plots.

Treatments were applied to caged enclosures $(51 \times$ $51 \times 81 \mathrm{~cm})$ and no-cage control plots $(51 \times 51 \mathrm{~cm})$ situated in a Zostera marina bed adjacent to Goodwin Islands, an archipelago in the York River estuary, Virginia, USA. (see Douglass et al. 2007 for a detailed description of cage construction). The cages were covered with $250 \mu \mathrm{m}$ mesh (Nytex) that permitted water circulation and passage of propagules, but prevented predator and grazer immigration and emigration. Before experimental treatments were applied, caged enclosures and no-cage control plots were defaunated with a liquid insecticide $\left(\right.$ Sevin $\left.^{\mathrm{TM}}\right)$. Douglass et al. (2007) described cage design and the defaunation process in greater detail. Grazer, predator and nutrient treatments were applied to the caged enclosures $4 \mathrm{~d}$ after defaunation. Grazer treatments consisted of an assemblage of 3 species, including an amphipod crustacean, Gammarus mucronatus (40 ind.), and 2 isopods, Idotea balthica (40 ind.) and Erichsonella attenuata (20 ind.). Predator treatments were stocked with 2 blue crabs Callinectes sapidus, with carapace widths of 20 to $40 \mathrm{~mm}$. Grazers and blue crabs were collected from the surrounding $Z$. marina bed immediately before addition to the cages and were stocked in proportions and abundances that reflected those in the field at the time of the experiment. Nutrient treatments were applied by suspending 2 perforated PVC tubes containing slow release fertilizer (Osmocote $^{\mathrm{TM}} ; \mathrm{N}: \mathrm{P}=$ 3:1) above the sediments. We added $200 \mathrm{~g}$ of Osmocote $^{\mathrm{TM}}$ during the first week and $400 \mathrm{~g}$ thereafter to achieve the desired and sustained level of enrichment. Contamination between fertilized and unfertilized treatments was prevented by spacing the cages $3 \mathrm{~m}$ apart. We deemed this distance to be sufficient to prevent cross-treatment contamination in a preliminary experiment. The experiment ran for $28 \mathrm{~d}$ during summer 2005. This time period was chosen to minimize the risk of invasion by non-target grazer species and to permit development of the animal and plant community and of surface sediment characteristics. During this time, temperature and salinity ranged from 23 to $27^{\circ} \mathrm{C}$ and from 15 to 19 , respectively (K. A. Moore unpubl. data). Biomasses of aboveground primary producers and animals in this experiment are reported by Douglass et al. (2007). Here, we focus on SOM composition.

Nutrient enrichment. Weekly, and immediately before the fertilizer was refreshed, $25 \mathrm{ml}$ of water were collected from 3 replicates of each treatment and filtered through a precombusted $\left(450^{\circ} \mathrm{C}\right)$ glass fiber filter. Water samples were initially chilled and later frozen $\left(-20^{\circ} \mathrm{C}\right)$ until they were analyzed for $\mathrm{NH}_{4}{ }^{+}$, $\left(\mathrm{NO}_{2}{ }^{-}+\mathrm{NO}_{3}{ }^{-}\right)$and $\mathrm{PO}_{4}^{-3}$ concentrations by standard methods with a Lachat auto-analyzer (Smith \& Bogren 2001, Knepel \& Bogren 2002, Liao 2002).

Light. To determine light levels we measured photosynthetically active radiation (PAR) in 10 randomly chosen cages, $14 \mathrm{~d}$ after they had been installed. The PAR measurements taken at 14 d represent realistic conditions within the cages since they were subjected to fouling. PAR measurements were taken with a spherical light meter (Li-Cor) in the eelgrass canopy both inside and outside of the cages. See Douglass et al. (2007) for more details.

Primary producers. Eelgrass and epiphyte biomass were determined at the end of the experiment. Eelgrass biomass was estimated from a grab sample $(20 \times$ $20 \mathrm{~cm}$ ) taken from the center of the cage. The samples were frozen at $-20^{\circ} \mathrm{C}$ until analysis (see Douglass et al. 2007 for details). Epiphyte biomass was estimated by scraping the fouling material from 5 eelgrass blades from each treatment onto a GFF filter (Whatman ${ }^{\mathrm{TM}}$ ) and measuring blade surface area with a 3100 area meter (Li-Cor). The filters were extracted in an acetone solution for $24 \mathrm{~h}$ before the extract was filtered and the absorbance measured using a UV-1601 spectrophotometer (Shimadzu). Epiphytic chlorophyll a (chl a) mass was calculated and normalized to blade area (see Douglass et al. 2007 for details). In addition, 3 sediment cores $(2.1 \mathrm{~cm}$ diameter) were collected to determine benthic chl a concentration, a measure of microalgal 
biomass. Subsamples from each core (upper $1 \mathrm{~cm}$ ) were combined in a scintillation vial to form a composite sample that was frozen at $-20^{\circ} \mathrm{C}$ until analysis. The samples were analyzed within $6 \mathrm{wk}$ of collection (Neubauer et al. 2000).

Bulk sediment organic matter (SOM). At the end of the experiment, 3 sediment cores of $2.6 \mathrm{~cm}$ diameter each were collected from every caged enclosure and no-cage control plot and analyzed for total organic carbon (TOC), total nitrogen (TN), and FA content. The upper $1 \mathrm{~cm}$ from each core was removed; subsamples from each core were combined into a composite sample in a precombusted $\left(450^{\circ} \mathrm{C}\right)$ jar. Samples were stored at $-80^{\circ} \mathrm{C}$. TOC and TN were analyzed by standard methods using a flash elemental analyzer (Fisons Model EA 1112) after removing inorganic carbon (Hedges \& Stern 1984); acetanilide was used as the standard.

Fatty acid analyses. Fatty acids were analyzed using previously reported methods (Bligh \& Dyer 1959, Macnaughton et al. 1997). Briefly, sediment samples were extracted with methanol:chloroform: $\mathrm{K}_{2} \mathrm{HPO}_{4}(50 \mathrm{mM})$ buffer $(2: 1: 0.8, \mathrm{v}: \mathrm{v}: \mathrm{v})$ using an accelerated solvent extraction system (Dionex ASE 200). Following extraction, the samples were partitioned and the organic phase removed. Anhydrous $\mathrm{Na}_{2} \mathrm{SO}_{4}$ was added to the organic phase to remove water overnight. The samples were concentrated to $1 \mathrm{ml}$ (Zymark Turbo Vap 500) and then saponified (Arzayus \& Canuel 2005). Following saponification, the residue was extracted under basic (saponified-neutral) and acidic pH (saponifiedacid). The saponified acid fraction was methylated using $\mathrm{BF}_{3}-\mathrm{CH}_{3} \mathrm{OH}$ and purified using silica gel chromatography. Before analysis by gas chromatography (GC), samples were evaporated to dryness under $\mathrm{N}_{2}$ and a small volume of hexane was added. The FAs, as methyl esters, were analyzed by gas chromatography (Canuel \& Martens 1993, Zimmerman \& Canuel 2001). Peaks were quantified relative to an internal standard, methyl heneicosanoate, added just prior to GC analysis. Peak identities were verified using reference standards and by combined gas chromatography-mass spectrometry using a Hewlett-Packard 6890 GC interfaced with a mass selective detector operated in electron impact mode. FAs are designated as $\mathrm{A}: \mathrm{B} \omega \mathrm{C}$, where $\mathrm{A}$ is the total number of carbon atoms, $\mathrm{B}$ is the number of the double bonds, and $\mathrm{C}$ is the position of the first double bond from the aliphatic ' $\omega$ ' end of the molecule. The prefixes ' $i$ ' and ' $a$ ' refer to iso- and anteiso-methyl branched FAs (see Canuel et al. 1995 and references therein).

Statistical analyses. To determine the effect of cage presence on primary producer biomass and SOM content and composition, we conducted 1-way ANOVA using SAS v.9.1 for Microsoft Windows. Only the no- cage controls and caged treatments with grazers and predators were included in the analyses since those treatments only varied in the presence of cages.

The whole experiment was analyzed as a fully factorial 3-way ANOVA, with grazer treatment $(\mathrm{df}=1)$, predator treatment $(\mathrm{df}=1)$ and nutrient addition $(\mathrm{df}=$ 1) as fixed variables. Analyses of FAs were conducted on concentration data normalized to total FA abundance ( $\%$ total FAs). Data were transformed by log or arcsine square root functions as necessary to maintain homogeneity of variance as determined by the Cochran's $C$-test. From the ANOVAs we calculated the magnitude of main and interactive effects $\left(\omega^{2}\right.$, percentage of variance explained). Due to failure of caged enclosures (e.g. tears or holes in the Nytex mesh) 7 replicates were removed from the final statistical analyses. No-cage control plots were also excluded from the final ANOVA since their inclusion would have resulted in an unbalanced statistical design. Thus, 33 replicates were used in statistical analyses: caged control treatments had 4 replicates in each nutrient condition, grazer treatments had 4 replicates with nutrients and 5 without, crab treatments had 3 replicates with nutrients and 4 without, and combined grazer and predator treatments had 5 replicates with nutrients and 4 without. Results presented use the type III sum of squares (SS) from the ANOVA models.

To interpret the bulk SOM and FA data, we performed multiple regression and principal components analyses (PCA; Minitab 14 statistical software). Multiple regression tests modeled \% TOC, \% TN and the FA groups as functions of Zostera marina biomass, epiphytic chl $a$ and benthic chl $a$. The partial $r^{2}$ was calculated by dividing the type III SS for each response variable by the total SS. In the PCA, we included $Z$. marina biomass, epiphytic chl $a$, benthic chl $a$, \% TOC, \% TN and FA groups. PCA yielded loadings and scores, which described correlations between dominant principal components and response variables (loadings) and observations (scores). PCA loadings were regressed against $Z$. marina biomass, epiphytic chl a and benthic chl a to help interpret the nondimensional results.

\section{RESULTS}

\section{Cage effects}

Field cages reduced photosynthetically active radiation by $66 \%$ relative to ambient, to an average of $262 \mu \mathrm{E} \mathrm{s}^{-1} \mathrm{~m}^{-2}$, which is within the range of saturating irradiance for Zostera marina. One-way ANOVAs, comparing the no-cage controls to the caged treatments with grazers and predators, showed that cages 
reduced $Z$. marina biomass ( $p<0.001)$, epiphytic chl a $(\mathrm{p}<0.001)$, benthic chl a $(\mathrm{p}=0.008)$ and total FA abundance $(p=0.005)$, but increased bacterial FAs (\%BrFA, $\mathrm{p}=0.015 ; \% 10 \mathrm{Me} 17: 0, \mathrm{p}=0.001$ ) (Figs. $1 \& 2$, see Fig. 4).

\section{Nutrient concentrations}

During the first week of the experiment, nutrient treatments received $200 \mathrm{~g}$ of Osmocote ${ }^{\mathrm{TM}}$, which increased the concentration of $\left(\mathrm{NO}_{2}{ }^{-}+\mathrm{NO}_{3}{ }^{-}\right)(\mathrm{p}<$ 0.001 ), but not of $\mathrm{NH}_{4}{ }^{+}$or $\mathrm{PO}_{4}{ }^{-3}$. For the remainder of
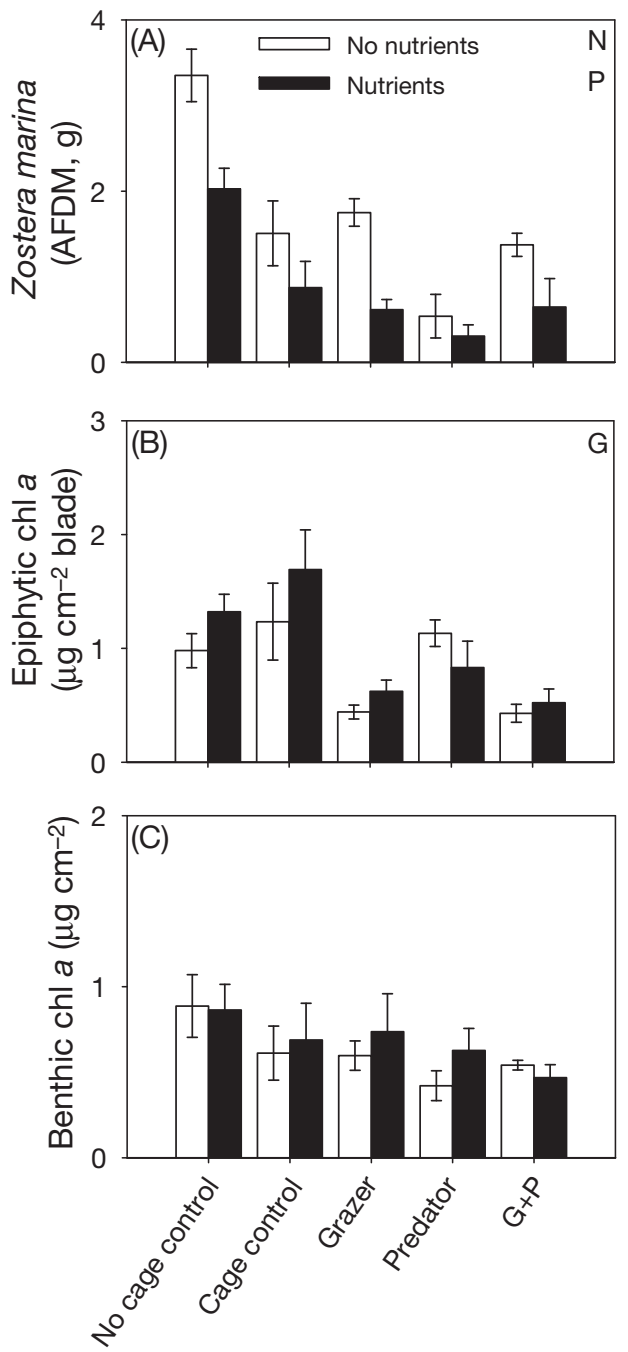

Fig. 1. Effects of nutrient enrichment, predators and grazers on (A) Zostera marina, (B) epiphytic chl a and (C) benthic chl a. The presence of cages reduced the abundance of all 3 primary producers. Nutrient enrichment and predators reduced $Z$. marina abundance while grazers reduced epiphytic chl a. Statistical results in Table 2. Error bars: SE; significant treatment effects: $\mathrm{N}=$ nutrient enrichment, $\mathrm{P}=\mathrm{crab}$ predators, $\mathrm{G}=$ grazers the experiment, Osmocote ${ }^{\mathrm{TM}}$ additions were increased to $400 \mathrm{~g}$, thereby raising the concentrations of $\left(\mathrm{NO}_{2}{ }^{-}+\right.$ $\mathrm{NO}_{3}{ }^{-}$), $\mathrm{NH}_{4}{ }^{+}$and $\mathrm{PO}_{4}$ (all $\mathrm{p}<0.001$; Table 1).

Table 1. Average concentration $(\mu \mathrm{M})$ of water column nutrients sampled on Days 14 and 23 of the experiment when Osmocote ${ }^{\mathrm{TM}}$ additions were $400 \mathrm{~g}$ per treatment. Concentrations were higher in nutrient versus non-nutrient treatments $(\mathrm{p}<0.001)$

\begin{tabular}{|lcccc|}
\hline Nutrients & \multicolumn{2}{c}{$\begin{array}{c}\text { Nutrient treatment } \\
\text { Day 14 }\end{array}$} & Day 23 & No nutrient treatment \\
Day 14 & Day 23 \\
\hline $\mathrm{NO}_{2}{ }^{-}+\mathrm{NO}_{3}{ }^{-}$ & 5.55 & 6.31 & 0.11 & 0.29 \\
$\mathrm{NH}_{4}{ }^{-}$ & 4.98 & 8.45 & 0.69 & 2.28 \\
$\mathrm{PO}_{4}{ }^{-3}$ & 0.27 & 0.57 & 0.01 & 0.09 \\
\hline
\end{tabular}
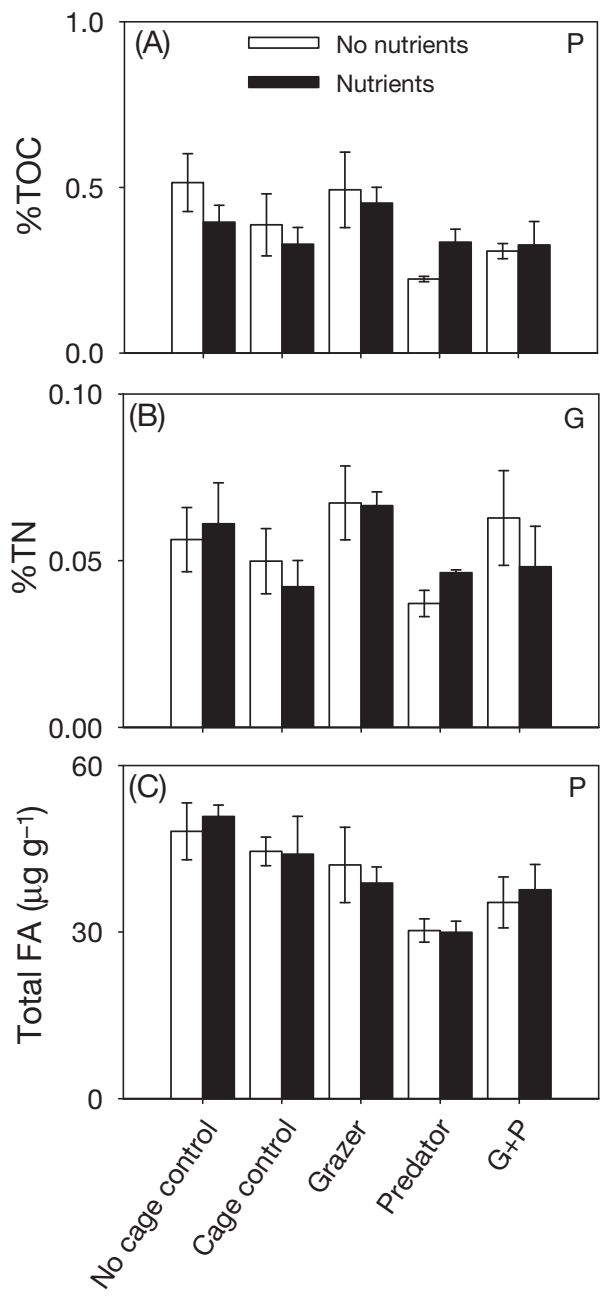

Fig. 2. Predators and grazers affected abundances of (A) organic carbon (\%TOC), (B) total nitrogen (\% TN) and (C) total fatty acids (FAs) in the sediment. Predators decreased \% TOC and total FAs while grazers increased \%TN. Nutrient enrichment did not affect \%TOC, \% TN or total FAs. Symbols and statistical analysis are as described in Fig. 1 
Table 2. Tests of significance and estimated magnitudes of effect $\left(\omega^{2}\right)$ for nutrient level, predator presence, grazer presence and their interactions on plant biomass, sediment total nitrogen, sediment organic carbon and sediment fatty acid abundance. Except where noted, analyses were performed on untransformed data. When an interaction between nutrients and predators or grazers was significant, the data set was divided according to the interaction (i.e. nutrients, NT, versus no nutrients, NNT), and an ANOVA was performed again. For interactive effects: $\mathrm{G}=$ grazers, $\mathrm{P}=$ predators, $\mathrm{N}=$ nutrients. Bold: significant relationships

$$
(\mathrm{p}<0.05)
$$

\begin{tabular}{|c|c|c|c|c|c|c|c|c|c|c|c|c|c|c|c|}
\hline & \multicolumn{3}{|c|}{ Nutrients } & \multicolumn{3}{|c|}{ — Predators — } & \multicolumn{3}{|c|}{ - Grazers } & & \multicolumn{3}{|c|}{ _ Interactions- } & \multicolumn{2}{|c|}{ — Error- } \\
\hline & MS & $\mathrm{p}$ & $\omega^{2}$ & MS & $\mathrm{p}$ & $\omega^{2}$ & MS & $\mathrm{p}$ & $\omega^{2}$ & & MS & $\mathrm{p}$ & $\omega^{2}$ & MS & $\omega^{2}$ \\
\hline Zostera marina (AFDM) & 3.76 & 0.001 & 0.21 & 1.79 & 0.017 & 0.09 & 0.68 & 0.128 & 0.02 & & & & & 0.27 & 0.65 \\
\hline ln epiphytic chl $a$ & 0.10 & 0.468 & 0.00 & 0.48 & 0.119 & 0.02 & 5.93 & $<0.001$ & 0.43 & & & & & 0.18 & 0.55 \\
\hline Benthic chl a & 0.06 & 0.380 & 0.00 & 0.17 & 0.152 & 0.03 & 0.00 & 0.987 & 0.00 & & & & & 0.08 & 1.08 \\
\hline$\%$ TOC & 0.00 & 0.875 & 0.00 & 0.11 & 0.032 & 0.10 & 0.05 & 0.152 & 0.03 & & & & & 0.02 & 0.94 \\
\hline$\% \mathrm{TN}$ & 0.00 & 0.628 & 0.00 & 0.00 & 0.279 & 0.01 & 0.00 & 0.022 & 0.12 & & & & & 0.00 & 0.95 \\
\hline Total FAs $\left(\mu g g^{-1}\right)$ & 1.62 & 0.898 & 0.00 & 664.03 & 0.014 & 0.14 & 12.91 & 0.717 & 0.00 & & & & & 96.10 & 0.92 \\
\hline$\% \mathrm{SCFA}^{\mathrm{a}}$ & 1.81 & 0.014 & 0.11 & 1.52 & 0.024 & 0.09 & 1.45 & 0.026 & 0.08 & $\mathrm{G} \times \mathrm{P}$ & 2.38 & 0.006 & 0.15 & 0.26 & 0.72 \\
\hline$\% \mathrm{C}_{16: 0}$ & 0.03 & 0.909 & 0.00 & 0.74 & 0.569 & 0.00 & 20.81 & 0.005 & 0.17 & & & & & 2.22 & 0.80 \\
\hline$\% \mathrm{C}_{18: 0}$ & 1.07 & 0.164 & 0.03 & 2.45 & 0.040 & 0.09 & 0.42 & 0.380 & 0.00 & & & & & 0.52 & 0.96 \\
\hline$\%$ LCFA $^{b}$ & 1.00 & 0.454 & 0.00 & 3.33 & 0.177 & 0.02 & 14.04 & 0.009 & 0.13 & $\mathrm{~N} \times \mathrm{P}$ & 9.76 & 0.025 & 0.09 & 1.72 & 0.75 \\
\hline NNT & & & & 12.78 & 0.014 & 0.20 & 12.32 & 0.015 & 0.19 & & & & & 1.58 & 0.56 \\
\hline NT & & & & 0.81 & 0.523 & 0.00 & 3.33 & 0.207 & 0.04 & & & & & 1.87 & 1.02 \\
\hline$\%\left(\mathrm{C}_{18: 2}+\mathrm{C}_{18: 3}\right)$ & 0.01 & 0.901 & 0.00 & 0.04 & 0.738 & 0.00 & 0.49 & 0.267 & 0.01 & & & & & 0.68 & 1.04 \\
\hline$\% \mathrm{C}_{20}$ PUFA $^{\mathrm{c}}$ & 0.22 & 0.713 & 0.00 & 0.77 & 0.494 & 0.00 & 10.58 & 0.017 & 0.09 & $\begin{array}{l}\mathrm{N} \times \mathrm{P} \\
\mathrm{G} \times \mathrm{P}\end{array}$ & $\begin{array}{l}22.14 \\
11.81\end{array}$ & $\begin{array}{l}0.001 \\
0.012\end{array}$ & $\begin{array}{l}0.21 \\
0.10\end{array}$ & 1.60 & 0.64 \\
\hline NNT & & & & 16.27 & 0.002 & 0.31 & 4.70 & 0.064 & 0.07 & $G \times P$ & 8.02 & 0.020 & 0.14 & 1.15 & 0.47 \\
\hline NT & & & & 7.03 & 0.092 & 0.09 & 5.89 & 0.120 & 0.07 & & & & & 2.10 & 0.80 \\
\hline$\% \mathrm{C}_{22}$ PUFA $^{\mathrm{d}}$ & 0.00 & 0.970 & 0.00 & 2.88 & 0.010 & 0.14 & 0.14 & 0.542 & 0.00 & $\mathrm{G} \times \mathrm{P}$ & 1.90 & 0.032 & 0.08 & 0.37 & 0.81 \\
\hline$\%\left(C_{16: 1 \omega 7}\right)$ & 3.92 & 0.608 & 0.00 & 0.51 & 0.852 & 0.00 & 126.60 & 0.007 & 0.18 & & & & & 14.50 & 0.91 \\
\hline $\mathrm{C}_{16: 1 \omega 7}: \mathrm{C}_{16: 0}$ & 0.02 & 0.526 & 0.00 & 0.01 & 0.756 & 0.00 & 0.65 & 0.002 & 0.23 & & & & & 0.05 & 0.85 \\
\hline $\mathrm{C}_{20: 5 \omega 3}: \mathrm{C}_{22: 6 \omega 3}$ & 4.41 & 0.291 & 0.00 & 96.83 & $<0.001$ & 0.26 & 78.98 & $<0.001$ & 0.21 & $\mathrm{G} \times \mathrm{P}$ & 43.23 & 0.002 & 0.11 & 3.78 & 0.42 \\
\hline$\% \mathrm{BrFA}^{\mathrm{e}}$ & 1.23 & 0.325 & 0.00 & 5.63 & 0.042 & 0.09 & 1.11 & 0.350 & 0.00 & & & & & 1.22 & 0.97 \\
\hline \%10Me17:0 & 0.31 & 0.007 & 0.17 & 0.30 & 0.008 & 0.16 & 0.01 & 0.698 & 0.00 & & & & & 0.04 & 0.90 \\
\hline $\begin{array}{l}\text { a } \% \text { SCFA represents } \%(C \\
\text { b } \% \text { LCFA represents } \%(C \\
\text { с } \% \mathrm{C}_{20} \text { PUFA represents } \\
\text { d } \% \mathrm{C}_{22} \text { PUFA represents } \\
\text { e } \% \text { BrFA ( } \Sigma \text { iso-, anteiso- }\end{array}$ & $\begin{array}{l}\mathrm{C}_{12: 0}+ \\
\mathrm{C}_{24: 0}^{+} \\
\%\left(\mathrm{C}_{20}\right. \\
\left(\mathrm{C}_{22: 5}\right. \\
\mathrm{C}_{13: 0}\end{array}$ & $\begin{array}{l}\left.\mathrm{C}_{14: 0}\right) \\
\mathrm{C}_{26: 0}+( \\
4+\mathrm{C}_{20} \\
+\mathrm{C}_{22: 6} \\
\mathrm{C}_{15: 0}, \mathrm{C}_{1}\end{array}$ & $\begin{array}{l}\left.C_{28: 0}\right) \\
5)\end{array}$ & & & & & & & & & & & & \\
\hline
\end{tabular}

\section{Primary producers}

Zostera marina biomass was decreased by the addition of nutrients and predators while epiphytes were reduced by grazers (Fig. 1, Table 2). In contrast, benthic chl a was insensitive to all 3 treatments.

\section{Bulk sediment organic matter (SOM)}

Sediment \% TOC was decreased by predators while $\%$ TN was increased by grazers (Fig. 2, Table 2). Neither \% TOC nor \% TN was influenced by nutrient addition nor was either variable correlated to the final biomass of any primary producer group (Table 3 ).

\section{Total fatty acids}

Within caged enclosures, predators decreased total FA abundance ( $\mu \mathrm{g} \mathrm{g}{ }^{-1}$ sediment; Fig. $2 \mathrm{C}$, Table 2), which was positively, but weakly, correlated to Zostera marina biomass (Table 3). In addition to total FA abundance, we analyzed FA composition by dividing total FAs into subclasses based on chain length, degree of saturation and carbon branching patterns; these groups represent different OM sources.

Algal and microbial contributions to SOM, represented by short chain saturated FAs $\left(\mathrm{SCFA} ; \%\left[\mathrm{C}_{12: 0}+\right.\right.$ $\left.\mathrm{C}_{14: 0}\right]$ ), were affected by resource level and food chain length. \%SCFA in treatments with nutrient additions was lower. Grazers increased \%SCFA in the absence of predators, resulting in a significant interaction between grazer and predator effects (Fig. 3A, Table 2).

Vascular plant contributions to SOM, represented by long chain FAs (LCFA; \% $\left[\mathrm{C}_{24: 0}+\mathrm{C}_{26: 0}+\mathrm{C}_{28: 0}\right]$ ), were also influenced by resource availability and food web composition. Grazers consistently increased \%LCFA (Fig. 3B, Table 2). Nutrient addition increased \%LCFA in the presence of predators, but decreased \%LCFA in the absence of predators, creating a nutrient $\times$ predator interaction effect. Surprisingly, \%LCFA correlated 
Table 3. Regression analyses of Zostera marina (ash-free dry mass, $\mathrm{g}$ ), benthic chl a $\left(\mu \mathrm{g} \mathrm{cm}^{-2}\right.$ ) and epiphytic chl a ( $\mu \mathrm{g} \mathrm{cm}^{-2}$ blade area) against bulk SOM and the FA groups (expressed as \% of total FAs). Partial $\mathrm{r}^{2}$ values were calculated by dividing the type III SS by the total SS. Signifcant relationships $(p<0.05)$ are in bold text

\begin{tabular}{|c|c|c|c|c|c|c|c|c|c|c|}
\hline & \multicolumn{3}{|c|}{ —Zostera marina } & \multicolumn{3}{|c|}{ Benthic chl $a-$} & \multicolumn{3}{|c|}{ - Epiphytic chl a } & \multirow{2}{*}{$\begin{array}{c}\text { Total } \\
\text { model } \mathrm{r}^{2}\end{array}$} \\
\hline & Coefficient & Partial $r^{2}$ & $\mathrm{p}$ & Coefficient & Partial $r^{2}$ & $\mathrm{p}$ & Coefficient & Partial $r^{2}$ & $\mathrm{p}$ & \\
\hline$\%$ TOC & 0.07 & 0.08 & 0.128 & 0.04 & 0.00 & 0.720 & 0.01 & 0.00 & 0.810 & 0.08 \\
\hline$\% \mathrm{TN}$ & 0.01 & 0.09 & 0.106 & -0.01 & 0.01 & 0.691 & 0.00 & 0.01 & 0.515 & 0.11 \\
\hline Total FAs $\left(\mu g^{-1}\right)$ & -1) 6.09 & 0.15 & 0.027 & -1.02 & 0.00 & 0.886 & 4.34 & 0.06 & 0.145 & 0.21 \\
\hline$\%$ SCFA $^{a}$ & 0.23 & 0.05 & 0.209 & 0.29 & 0.01 & 0.552 & -0.37 & 0.10 & 0.072 & 0.15 \\
\hline$\% \mathrm{C}_{16: 0}$ & 0.40 & 0.02 & 0.376 & -0.18 & 0.00 & 0.879 & -0.96 & 0.11 & 0.060 & 0.13 \\
\hline$\% \mathrm{C}_{18: 0}$ & 0.37 & 0.09 & 0.092 & 0.18 & 0.00 & 0.750 & 0.01 & 0.00 & 0.962 & 0.10 \\
\hline$\%$ LCFA $^{b}$ & 0.29 & 0.01 & 0.444 & 2.81 & 0.17 & 0.010 & -1.18 & 0.18 & 0.009 & 0.36 \\
\hline$\% \mathrm{C}_{20} \mathrm{PUFA}^{\mathrm{c}}$ & -0.29 & 0.01 & 0.486 & -2.59 & 0.13 & 0.027 & 1.18 & 0.16 & 0.015 & 0.31 \\
\hline$\% \mathrm{C}_{22}$ PUFA $^{\mathrm{d}}$ & 0.26 & 0.06 & 0.173 & -0.18 & 0.00 & 0.726 & 0.14 & 0.02 & 0.495 & 0.08 \\
\hline$\%\left(\mathrm{C}_{16: 1 \omega 7}\right)$ & -0.43 & 0.00 & 0.669 & -3.32 & 0.04 & 0.225 & 3.38 & 0.24 & 0.005 & 0.28 \\
\hline $\mathrm{C}_{16: 1 \omega 7}: \mathrm{C}_{16: 0}$ & -0.05 & 0.02 & 0.385 & -0.15 & 0.02 & 0.383 & 0.22 & 0.24 & 0.004 & 0.28 \\
\hline $\mathrm{C}_{20: 5 \omega 3}: \mathrm{C}_{22: 6 \omega 3}$ & -0.44 & 0.01 & 0.600 & -5.24 & 0.14 & 0.025 & 2.05 & 0.13 & 0.032 & 0.28 \\
\hline$\% \mathrm{BrFA}^{\mathrm{e}}$ & -0.84 & 0.23 & 0.003 & 1.06 & 0.05 & 0.129 & -0.96 & 0.25 & 0.002 & 0.53 \\
\hline$\% 10 \mathrm{Me} 17: 0$ & -0.22 & 0.40 & $<0.001$ & 0.28 & 0.08 & 0.048 & -0.11 & 0.07 & 0.063 & 0.56 \\
\hline \multicolumn{11}{|c|}{$\begin{array}{l}\text { a \%SCFA represents } \%\left(C_{12: 0}+C_{14: 0}\right) \\
\text { b \% }{ }_{0} \text { LFA represents } \%\left(C_{24: 0}+C_{26: 0}+C_{28: 0}\right) \\
\text { c \% } C_{20} \text { PUFA represents } \%\left(C_{20: 4}+C_{20: 5}\right) \\
\text { d \% } C_{22} \text { PUFA represents }\left(C_{22: 5}+C_{22: 6}\right) \\
\left.\text { e\%BrFA ( } \Sigma \text { iso-, anteiso- } C_{13: 0}, C_{15: 0}, C_{17: 0}, C_{19: 0}\right)\end{array}$} \\
\hline
\end{tabular}

positively with benthic chl $a$ and negatively with epiphytic chl $a$, and was not related to Zostera marina (Table 3). Since benthic chl a explained $17 \%$ of the variance it was probably a minor contributor to LCFA abundance.\%LCFA was positively, but weakly, correlated with abundances of 2 grazer species, the amphipod Gammarus mucronatus and the isopod Erichsonella attenuata, $\left(\mathrm{p}=0.004, \mathrm{r}^{2}=0.21\right.$ and $\mathrm{p}=0.031$, $\mathrm{r}^{2}=0.11$, respectively; data not shown).

The relative abundance of FAs deriving from labile algal sources, represented by polyunsaturated FAs (PUFA), was also affected by nutrient and food web manipulations (Fig. 3C,D, Table 2). We analyzed 2 groups of PUFA since they represent different types of algae; diatoms are a source of $\mathrm{C}_{20: 4}$ and $\mathrm{C}_{20: 5}$ while dinoflagellates are rich in $\mathrm{C}_{22: 5}$ and $\mathrm{C}_{22: 6}$. Hereafter $\left(\mathrm{C}_{20: 4}+\mathrm{C}_{20: 5}\right)$ will be referred to as $\mathrm{C}_{20}$ PUFA and $\left(\mathrm{C}_{22: 5}\right.$ $+\mathrm{C}_{22: 6}$ ) as $\mathrm{C}_{22}$ PUFA. Grazers decreased $\% \mathrm{C}_{20}$ PUFA but the grazing effect was eliminated in the presence of predators, resulting in a grazer by predator interaction. Predators only increased $\% \mathrm{C}_{20}$ PUFA in treatments without nutrient additions, creating a predator by nutrient interaction. $\% \mathrm{C}_{20}$ PUFA was correlated negatively with benthic chl $a$ and positively with epiphytic chl $a_{\text {; }}$ both correlations explained a small proportion of the variance in $\% \mathrm{C}_{20}$ PUFA (Table 3). Biomasses of the grazers Gammarus mucronatus and Erichsonella attenuata were negatively and weakly correlated with $\% \mathrm{C}_{20}$ PUFA $\left(\mathrm{p}=0.008, \mathrm{r}^{2}=0.18\right.$ and $\mathrm{p}=$ $0.012, r^{2}=0.16$, respectively; data not shown). Preda- tors decreased $\% \mathrm{C}_{22}$ PUFA in the absence of grazers, resulting in a grazer $\times$ predator interaction.

In addition to PUFA, we used 2 ratios $\left(\mathrm{C}_{16: 1 \omega 7}: \mathrm{C}_{16: 0}\right.$ and $\mathrm{C}_{20: 5 \omega 3}: \mathrm{C}_{22: 6 \omega 3}$ ) to determine the relative contributions of diatoms to sediment FA composition (Viso \& Marty 1993, Budge \& Parrish 1998, Shin et al. 2000). Grazers decreased both ratios and, hence, the abundance of diatom-derived FAs relative to contributions from other microalgae (Fig. 3E,F, Table 2). Predators increased diatom:dinoflagellate FAs $\left(\mathrm{C}_{20: 5 \omega 3}: \mathrm{C}_{22: 6 \omega 3}\right)$, but the magnitude was weaker in the presence of grazers and resulted in a grazer $\times$ predator interaction. Epiphytic chl a was positively correlated to both ratios while benthic chl a was negatively correlated to

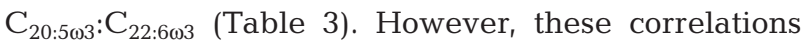
explained a small portion of the variance in $\mathrm{C}_{16: 1 \omega 7}: \mathrm{C}_{16: 0}$ and $\mathrm{C}_{20: 5 \omega 3}: \mathrm{C}_{22: 6 \omega 3}$. Biomass of the grazing isopod Idotea balthica was positively, but weakly, related to $\mathrm{C}_{20: 5 \omega 3}: \mathrm{C}_{22: 6 \omega 3}\left(\mathrm{p}=0.019, \mathrm{r}^{2}=0.12\right.$; data not shown). Combined, these data suggest that epiphytes were a source of diatom FAs in the sediments and that aboveground animal activities altered SOM supply and composition.

To examine how changes in SOM composition influenced the sediment bacterial community, we analyzed FAs representative of sediment bacterial OM (10Me17:0, and iso- and anteiso- $\mathrm{C}_{13: 0}, \mathrm{C}_{15: 0}, \mathrm{C}_{17: 0}, \mathrm{C}_{19: 0}$; Fig. 4). Predators increased the relative abundance of branched odd numbered FAs (\%BrFA; iso- and anteiso- $\mathrm{C}_{13: 0}, \mathrm{C}_{15: 0}, \mathrm{C}_{17: 0}, \mathrm{C}_{19: 0}$ ), representing sediment 

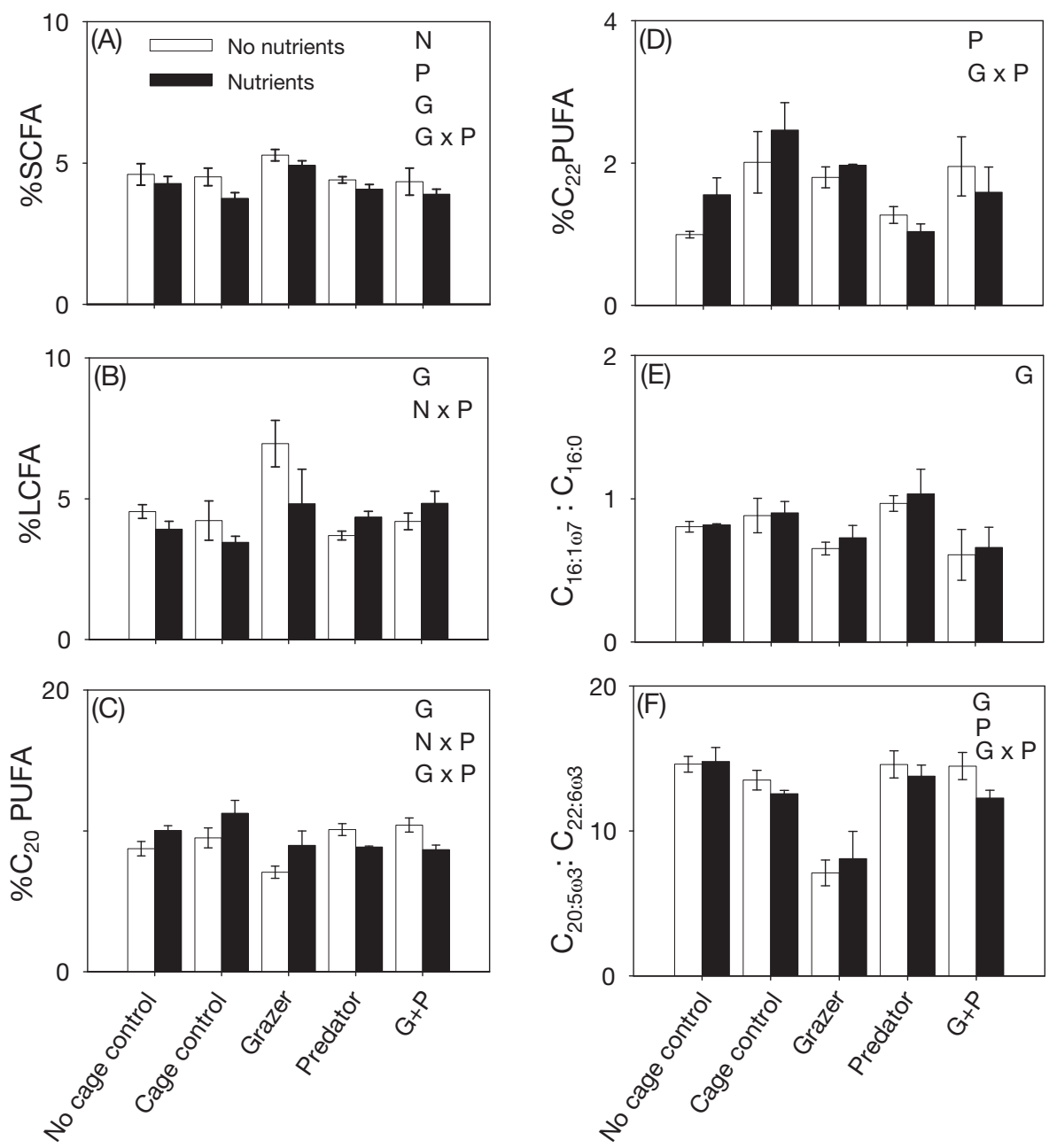

Fig. 3. (A to D) Effects of nutrients, predators and grazers on FA subclasses (expressed as \% of total FAs) representing plant and microbial sources of organic matter $(\mathrm{OM})$. Nutrients, predators and grazers had strong singular and interactive effects on plant and microbial contributions to the sediments. ( $\mathrm{E}$ to $\mathrm{F}$ ) The prevalence of OM deriving from diatoms, relative to other microalgae, was influenced by grazers and predators only. SCFA represents \% $\left(\mathrm{C}_{12: 0}+\mathrm{C}_{14: 0}\right)$; LCFA is \% $\left(\mathrm{C}_{24: 0}+\mathrm{C}_{26: 0}+\mathrm{C}_{28: 0}\right)$; $\mathrm{C}_{20}$ PUFA is $\%\left(\mathrm{C}_{20: 4}+\mathrm{C}_{20: 5}\right)$; and $\mathrm{C}_{22}$ PUFA is $\%\left(\mathrm{C}_{22: 5}+\mathrm{C}_{22: 6}\right)$. See 'Results, Total fatty acids' for biomarker sources. Symbols and statistical analysis are as described in Fig. 1

heterotrophic bacteria (Fig. 4A, Table 2). Correlations between \%BrFA and Zostera marina biomass and epiphytic chl a were negative and weak (Table 3). Nutrient addition and predators increased \%10Me17:0 (Fig. $4 \mathrm{~B}$, Table 2), a FA abundant in sulfate-reducing bacteria, which was correlated negatively to $Z$. marina and positively to benthic chl a (Table 3 ). These data suggest that food web structure, particularly predator presence, and resource levels influenced the sediment heterotrophic bacterial and microbial community.

Using PCA, we evaluated the effects of nutrient addition, grazers and predators on primary producer abundance, bulk SOM and FA groups. Principal components 1 (PC1) and 2 (PC2) explained 26.0 and $21.8 \%$, respectively, of the variance in the data. $\mathrm{PC} 1$ tended to separate treatments according to grazer effect; variables increased by grazers (\%TN, \%SCFA,
$\%$ LCFA and $\left.\% \mathrm{C}_{16: 0}\right)$ had positive loadings while those decreased by grazers (epiphytic chl $a, \% \mathrm{C}_{20}$ PUFA and $\% \mathrm{C}_{16: 11^{7}}$ ) had negative loadings (Fig. 5A). PC1 was correlated negatively to epiphytic chl a and positively to Zostera marina (Table 4). PC2 tended to separate variables according to predator effect; $Z$. marina biomass, $\%$ TOC, total FA and $\% \mathrm{C}_{22}$ PUFA were decreased by predators and had negative PC2 loadings while $\% \mathrm{BrFA}$ and \%10Me17:0 were increased by predators and had positive PC2 loadings (Fig. 5A). PC2 was negatively correlated to $Z$. marina biomass and epiphytic chl a (Table 4). Similar to PC loading results, PC scores separated treatments according to grazer and predator presence (Fig. 5B). Treatments with grazers were generally positive on PC1 while those with predators had negative scores. Along PC2, caged control treatments had negative scores while grazer and predator treat- 

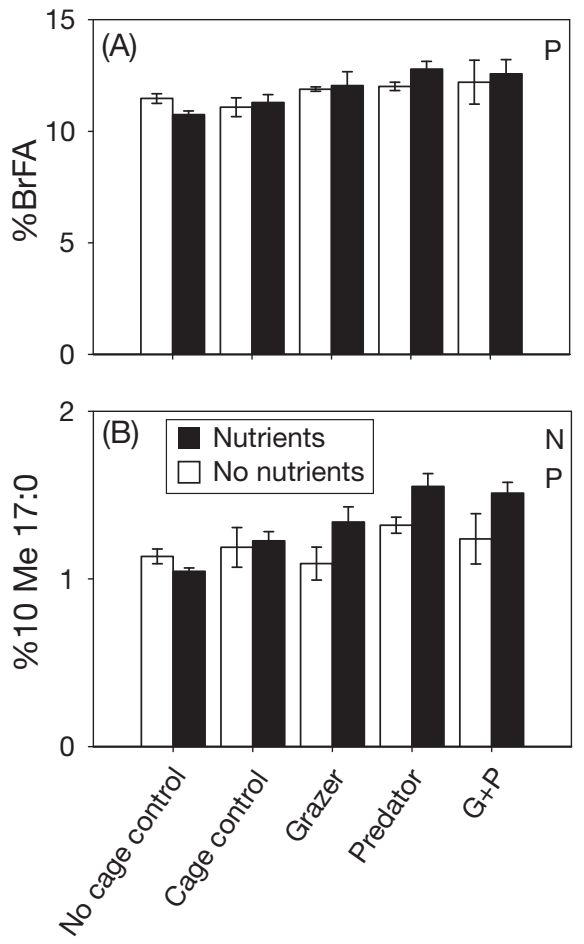

Fig. 4. Effects of nutrient enrichment and predators on the relative abundance of sediment heterotrophic bacterial FAs (expressed as \% of total FAs). The presence of cages increased abundances of \%BrFA ( $\mathrm{A}_{i} \Sigma$ [iso-, anteiso- $\mathrm{C}_{13: 0}+\mathrm{C}_{15: 0}+\mathrm{C}_{17: 0}+$ $\left.\mathrm{C}_{19: 0}\right]$ ) and \%10Me17:0 (B). Both \%BrFA and \%10Me17:0 were increased by predators but only \%10Me17:0 was increased by nutrient enrichment. Symbols and statistical analysis are as described in Fig. 1

ments were more positive. The combined grazer and predator treatment was near zero on PC1 and PC2 in the absence of nutrient addition and positive on PC2 in the presence of nutrient addition. Since the scores of the grazer and predator treatment and the predatoronly treatment were similar in treatments with nutrient additions, it is likely that under eutrophic conditions predators were stronger determinants of SOM composition than were grazers. Combined, our PCA results suggest that food web composition strongly influences FA contributions from primary producers and that nutrient additions tended to shift the composition of the primary producer community towards a dominance of epiphytes and a loss of Z. marina.

\section{DISCUSSION}

Our results show that both nutrient enrichment and food web composition can have dramatic effects on the quality of organic matter (OM) deposited to estuarine sediments. Nutrient enrichment created an early increase in epiphytic algae (Douglass et al. 2007) that
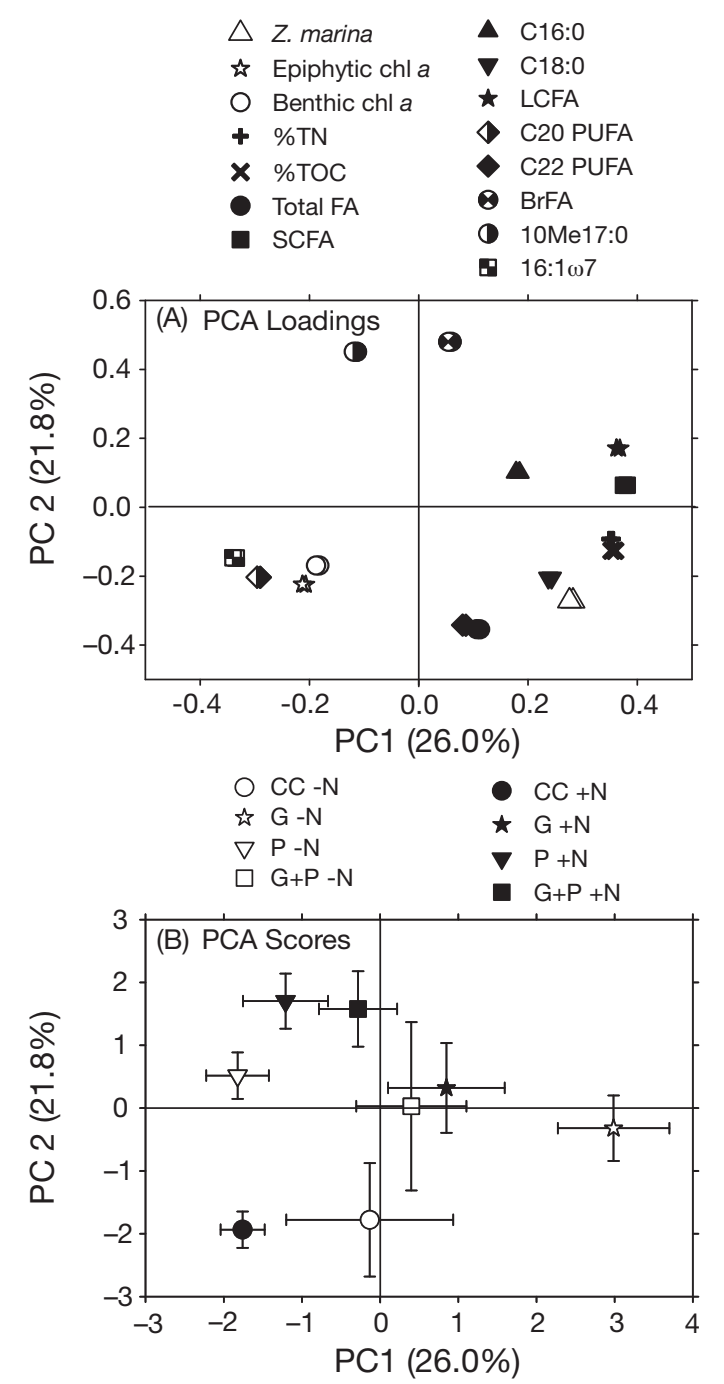

Fig. 5. (A) Loadings and (B) score plots from principal component analysis (PCA) for primary producers, sediment organic carbon, sediment nitrogen and sediment FA groups. In (A), the following abbreviations were used: SCFA $=\%\left(\mathrm{C}_{12: 0}+\right.$ $\left.\mathrm{C}_{14: 0}\right), \mathrm{LCFA}=\%\left(\mathrm{C}_{24: 0}+\mathrm{C}_{26: 0}+\mathrm{C}_{28: 0}\right), \mathrm{C}_{20} \mathrm{PUFA}=\%\left(\mathrm{C}_{20: 4}+\right.$ $\left.\mathrm{C}_{20: 5}\right), \mathrm{C}_{22}$ PUFA $=\%\left(\mathrm{C}_{22: 5}+\mathrm{C}_{22: 6}\right)$ and BrFA $=\%$ (iso-, anteiso$\mathrm{C}_{13: 0}+\mathrm{C}_{15: 0}+\mathrm{C}_{17: 0}+\mathrm{C}_{19: 0}$ ). In (B), $+\mathrm{N}$ : nutrients, $-\mathrm{N}$ : no nutrients, CC: caged control, G: grazers, P: predators, G+P: combined grazers and predators. Correlations between PC1, PC2 and the primary producers are listed in Table 4 . Error bars: SE

was not evident by the end of the experiment after grazer populations had increased substantially (Fig. 1B, Table 2). As such, there was no resultant increase in algal-derived FAs in nutrient enriched treatments (i.e. $\%$ SCFA, $\% \mathrm{C}_{20}$ PUFA, $\% \mathrm{C}_{22}$ PUFA). Although grazers reduced epiphytic algae and, potentially, resource competition between primary producers, this did not result in higher eelgrass or benthic algal abundances. Instead, grazing on epiphytic algae probably reduced relative abundances of algal- 
Table 4. Regression analyses of Zostera marina (ash-free dry mass, g), benthic chl a $\left(\mu \mathrm{g} \mathrm{cm}^{--2}\right.$ ) and epiphytic Chl a ( $\mu \mathrm{g} \mathrm{cm}^{-2}$ blade area) against principal components 1 (PC1) and 2 (PC2). Partial $\mathrm{r}^{2}$ values were calculated by dividing the type III SS by the total SS. Bold: significant $(\mathrm{p}<0.05)$

\begin{tabular}{|c|c|c|c|c|c|c|c|c|c|c|}
\hline \multirow{2}{*}{$\begin{array}{l}\text { Principal } \\
\text { component }\end{array}$} & \multicolumn{3}{|c|}{ Zostera marina $ـ$} & \multicolumn{3}{|c|}{ Benthic chl $a$} & \multicolumn{3}{|c|}{ Epiphytic chl $a$} & \multirow{2}{*}{$\begin{array}{c}\text { Total } \\
\text { Model } \mathrm{r}^{2}\end{array}$} \\
\hline & Coefficient & Partial $r^{2}$ & $\mathrm{p}$ & Coefficient & Partial $r^{2}$ & $\mathrm{p}$ & Coefficient & Partial $r^{2}$ & $\mathrm{p}$ & \\
\hline PC1 & 1.30 & 0.17 & 0.004 & 1.38 & 0.03 & 0.225 & -1.49 & 0.19 & 0.003 & 0.39 \\
\hline $\mathrm{PC} 2$ & -1.65 & 0.34 & $<0.001$ & 1.67 & 0.05 & 0.086 & -1.77 & 0.32 & $<0.001$ & 0.70 \\
\hline
\end{tabular}

derived SOM ( $\% \mathrm{C}_{20}$ PUFA, $\left.\mathrm{C}_{16: 1 \omega 7}: \mathrm{C}_{16: 0}, \mathrm{C}_{20: 5 \omega 3}: \mathrm{C}_{22: 6 \omega 3}\right)$. Predators also affected the relative contributions of FA subclasses to sediments, but these effects were often moderated by the grazer community, suggesting that trophic interactions are important mediators of SOM composition. Surprisingly, presence of grazers was a stronger determinant of SOM composition and quality than resource levels (nutrient additions) or predator presence. Perhaps most importantly, our results indicate that changes in food web composition and resource availability can have strong effects on SOM composition over a short time period in a natural seagrass bed subject to the numerous other influences operating in the field.

\section{Nutrient enrichment and SOM composition}

Contrary to our initial hypotheses, nutrient enrichment did not increase epiphytic biomass by the end of the experiment (Douglass et al. 2007). It is likely that rapid grazer population growth coupled with efficient grazer consumption of aboveground algae prevented the accumulation of epiphytes on eelgrass blades (Jernakoff \& Nielsen 1997, Heck et al. 2000, Hughes et al. 2004, Heck \& Valentine 2006, Valentine \& Duffy 2006) (Fig. 1B, Table 2). The absence of a positive effect of nutrient enrichment on epiphytic and benthic algae was mirrored by a general lack of main nutrient effects on SOM composition. However, interactions between nutrient enrichment and predator presence suggest that top-down and bottom-up controls moderate SOM composition jointly (Fig. 3B,C). Despite a general insensitivity of SOM composition to nutrient enrichment, nutrient additions resulted in higher relative abundances of $10 \mathrm{Me} 17: 0$, a FA common in sulfatereducing bacteria. However, nutrient additions did not elicit similar responses on BrFA, an additional class of biomarkers for heterotrophic bacteria. The contrast between these 2 results suggests that BrFA and 10Me17:0 may reflect different bacterial communities. For instance, \%BrFA was negatively related to epiphytic chl a while \%10Me17:0 correlated positively with benthic chl a (Table 3). This suggests that bacteria represented by BrFA responded to early epiphytic OM deposition, which gradually decreased as grazer populations grew. As benthic chl a became a proportionately greater source of labile SOM, sulfate-reducing bacterial metabolism and production of 10Me17:0 probably increased. Higher rates of heterotrophic bacterial activity may have reduced sediment oxygen availability and increased sulfide production, creating conditions that can be toxic to seagrass (Hemminga 1998, Calleja et al. 2007, Perez et al. 2007). This is supported by the negative correlations between Zostera marina and both bacterial FA groups (Table 3). Consequently, nutrient addition may have indirectly affected seagrass survival by altering SOM composition, heterotrophic bacterial activity and, thus, sediment redox conditions.

\section{Aboveground community structure and SOM composition}

Surprisingly, Zostera marina biomass was strongly reduced by predator presence. Unnatural confinement of predators may have contributed to $Z$. marina decline through crab destruction of the grass blades (Douglass et al. 2007). Loss of $Z$. marina corresponded with lower $\%$ TOC and total FA abundance, possibly due to lower effectiveness of the grass in trapping fine sediment and particulate OM (Bouillon et al. 2004, de Boer 2007) (Figs. $1 \& 2$, Table 2). This is consistent with the positive correlation between $Z$. marina and total FA abundances (Table 3). Predators influenced SOM composition by decreasing labile OM from algal and microbial sources (\%SCFA and $\% \mathrm{C}_{22}$ PUFA) and \%LCFA (ambient nutrients only; Fig. 3, Table 2). This was opposite to previous experimental findings where blue crabs reduced grazers and increased algal biomass and algal FAs in the sediment (Duffy et al. 2005, Canuel et al. 2007). Despite the negative effect of predators on several primary producer FA groups, predators increased diatom-derived FAs (e.g. higher ratio of $\mathrm{C}_{20: 5 \omega 3}: \mathrm{C}_{22: 6 \omega 3 i}$ Fig. 3, Table 2) and, perhaps as a result, sediment heterotrophic bacterial FAs (\%BrFA and \%10Me17:0; Fig. 4, Table 2). The positive predator effect on $\%$ BrFA is consistent with previous seagrass mesocosm experiments (Canuel et al. 2007, Spivak et al. 2007) and sug- 
gests that the aboveground community's effects on primary producers can penetrate to influence sediment bacteria. Thus, food chain length could have important indirect effects on sediment bacterial processes such as OM decomposition and remineralization.

Overall, grazer community effects on SOM composition tended to be stronger than nutrient enrichment or predator presence. This was probably due to the strong negative effect of grazers on epiphytes that translated into lower relative abundances of algal derived FAs in the sediment $\left(\% \mathrm{C}_{20}\right.$ PUFA, $\mathrm{C}_{20: 5 \omega 3}$ : $\mathrm{C}_{22: 6 \omega 3}, \mathrm{C}_{16: 1 \omega 7}: \mathrm{C}_{16: 0 ;}$ Fig. 3). It was surprising that the relative abundances of SCFA and LCFA, representing algal and microbial OM and vascular plant OM, respectively, were higher in grazer-only treatments. However, it is possible that grazer feeding was selective (Jernakoff \& Nielsen 1997, Valentine \& Duffy 2006) and that grazers did not consume OM sources of SCFA and LCFA. Consequently, grazers reduced the relative contributions of epiphytic FAs to the sediments but increased the relative contributions from the microphytobenthos. There was some evidence of crabs suppressing or inhibiting grazers, thereby creating a trophic cascade, as diatom derived FAs were proportionately more abundant in combined grazer and predator treatments than in grazer-only treatments (Fig. 3C,F). Our field results confirm previous findings from mesocosm experiments (Canuel et al. 2007, Spivak et al. 2007) that grazers influence SOM quality and lability and that these effects indirectly influence sediment bacterial community composition and contributions from bacterial biomass.

The importance of the aboveground animal community in determining primary producer biomass and SOM content and composition is summarized by the PCA results (Fig. 5). PC1 scores indicated that Zostera marina was more abundant in grazer-only treatments while epiphytes were more abundant in treatments with predators or without any animals (Table 4). Nutrient enrichment tended to shift all of the treatments towards more negative PC1 scores, indicating higher epiphytic biomass. Predators may have exerted greater influence over SOM composition than did grazers under elevated nutrient conditions. This was suggested by similar PCA scores for the predator-only and the combined grazer and predator treatments. The data also indicated that the presence of a food web strongly affected the primary producer community since PC2 separated treatments according to the presence or absence of animals. Thus, our results demonstrate that SOM composition responds relatively rapidly to changes in the abundance and composition of primary producers precipitated by shifts in trophic structure and resource availability. Consequently, episodic shifts in community composition and resource levels have the potential to rapidly influence sediment processes and ecosystem functioning.

\section{Interexperimental comparisons}

Previously, we conducted mesocosm experiments to determine how food web composition and light levels affected the composition and quality of SOM (Canuel et al. 2007, Spivak et al. 2007). The value of these experiments depends, in part, on how accurately the mesocosm system mimics the natural environment. There were many similarities between the experiments, but several important differences also existed. For instance, grazers increased the proportion of benthic algal and microbial SCFA in the sediment in both the present field experiment and a previous mesocosm experiment (Canuel et al. 2007). Predators reduced OM contributions from labile algae (PUFA) in both the present field experiment and a mesocosm experiment (Spivak et al. 2007). Predator presence also affected the sediment bacterial community as we observed higher proportions of heterotrophic bacterial FAs in predator treatments across all 3 experiments. In addition there was evidence that resource levels influenced SOM composition as shading (Spivak et al. 2007) and nutrient addition (this study) decreased Zostera marina biomass and SOM derived from algae and microbes (SCFA). The general similarities between this and previous experiments are encouraging and suggest that conditions in the mesocosms reflected the natural environment in important ways.

Differences between the field and mesocosm experiments confirm that both types of experiments introduce artifacts. However, when used in combination, field and mesocosm experiments provide realistic insights into trophic interactions and ecosystem processes. For example, benthic chl a was reduced by grazers in both mesocosm experiments (Canuel et al. 2007, Spivak et al. 2007), but not in the field experiment (present study). It is possible that benthic algae were reduced because grazers attained a much higher biomass in the mesocosm experiment (Duffy et al. 2005, Canuel et al. 2007) than in the field experiment. A more likely explanation is that benthic algal production was light-limited in the field experiment, where water was turbid and deeper than in the mesocosms. Also the field cages in the experiment reduced light levels by $66 \%$. The negative effect of cages on light levels may have reduced abundances of Zostera marina, epiphytes and total FAs. Despite the negative effect of caging on primary producer biomass, we were still able to detect the effects of the food web and nutrient manipulations on eelgrass and algal abundances and their contributions to the sediments. Thus, it is pos- 
sible that differences between treatments would have been more pronounced if light levels not been reduced. Future research efforts that combine field experiment and mesocosm approaches offer the potential to provide environmentally meaningful insights about the effects of bottom-up and top-down processes on aquatic ecosystems.

Acknowledgements. We thank R. E. Blake, K. E. France, L. A. Moore and N. Yavit for help maintaining and sampling the field cages; H. Walker and B. B. Neikirk for analyzing water samples for nutrient concentrations; and M. A. Cochran and M. A. Wunderly for assistance in the lab. I. C. Anderson, D. Bronk and J. J. Stachowicz provided valuable input on experimental goals and design. This manuscript was improved by comments from M. F. Pedersen and 2 anonymous reviewers. This work was made possible through a NSF grant (OCE 0352343) to J.E.D. and a NCER, STAR program, EPA grant (FP91656901) to A.C.S.. E.A.C. was supported by NSF awards DEB-0542645 and DEB-0454736 during the study period. Although the research described in the article has been funded in part by the U.S. EPA's STAR program, it has not been subjected to any EPA review and therefore does not necessarily reflect the views of the agency, and no official endorsement should be inferred. Additional support was provided by Virginia Institute of Marine Science. This article is contribution no. 2975 of the Virginia Institute of Marine Science, The College of William and Mary.

\section{LITERATURE CITED}

Arzayus KM, Canuel EA (2005) Organic matter degradation in sediments of the York River estuary: effects of biological vs. physical mixing. Geochim Cosmochim Acta 69: 455-464

Bligh EG, Dyer WJ (1959) A rapid method of total lipid extraction and purification. Can J Biochem Physiol 37:911-917

Boschker HTS, Cappenberg TE (1998) Patterns of extracellular enzyme activities in littoral sediments of Lake Gooimeer, The Netherlands. FEMS Microbiol Ecol 25: 79-86

Bouillon S, Moens T, Dehairs F (2004) Carbon sources supporting benthic mineralization in mangrove and adjacent seagrass sediments (Gazi Bay, Kenya). Biogeosciences 1: 71-78

Budge SM, Parrish CC (1998) Lipid biogeochemistry of plankton, settling matter and sediments in Trinity Bay, Newfoundland. II. Fatty acids. Org Geochem 29:1547-1559

Burkepile DE, Hay ME (2006) Herbivore vs. nutrient control of marine primary producers: context-dependent effects. Ecology 87:3128-3139

Calleja ML, Marba N, Duarte CM (2007) The relationship between seagrass (Posidonia oceanica) decline and sulfide porewater concentration in carbonate sediments. Estuar Coast Shelf Sci 73:583-588

Canuel EA, Martens CS (1993) Seasonal variations in the sources and alteration of organic matter associated with recently-deposited sediments. Org Geochem 20:563-577

Canuel EA, Martens CS (1996) Reactivity of recently deposited organic matter: degradation of lipid compounds near the sediment-water interface. Geochim Cosmochim Acta 60:1793-1806

Canuel EA, Cloern JE, Ringelberg DB, Guckert JB, Rau GH
(1995) Molecular and isotopic tracers used to examine sources of organic matter and its incorporation into the food webs of San Francisco Bay. Limnol Oceanogr 40: $67-81$

Canuel EA, Spivak AC, Waterson EJ, Duffy JE (2007) Biodiversity and food web structure influence short-term accumulation of sediment organic matter in an experimental seagrass system. Limnol Oceanogr 52:590-602

Carpenter SR, Kitchell JF, Hodgson JR (1985) Cascading trophic interactions and lake productivity. Bioscience 35: 634-639

Cebrian J (1999) Patterns in the fate of production in plant communities. Am Nat 154:449-468

Cebrian J, Duarte CM (2001) Detrital stocks and dynamics of the seagrass Posidonia oceanica (L.) Delile in the Spanish Mediterranean. Aquat Bot 70:295-309

Chase JM, Leibold MA, Downing AL, Shurin JB (2000) The effects of productivity, herbivory, and plant species turnover in grassland food webs. Ecology 81:2485-2497

$>$ Cloern JE (2001) Our evolving conceptual model of the coastal eutrophication problem. Mar Ecol Prog Ser 210: $223-253$

Dalsgaard J, John MS, Kattner G, Muller-Navarrra D, Hagen W (2003) Fatty acid trophic markers in the pelagic marine environment. In: Southward A, Tyler P, Young C, Fuiman L (eds) Advances in marine biology, Vol 46. Academic Press, London, p 225-340

de Boer WF (2007) Seagrass-sediment interactions, positive feedbacks and critical thresholds for occurrence: a review. Hydrobiologia 591:5-24

> Douglass JG, Duffy JE, Spivak AC, Richardson JP (2007) Nutrient versus consumer control of community structure in a Chesapeake Bay eelgrass habitat. Mar Ecol Prog Ser 348:71-83

Duarte CM (2002) The future of seagrass meadows. Environ Conserv 29:192-206

Duarte CM, Cebrian J (1996) The fate of marine autotrophic production. Limnol Oceanogr 41:1758-1766

Duarte CM, Middelburg JJ, Caraco N (2005) Major role of marine vegetation on the oceanic carbon cycle. Biogeosciences $2: 1-8$

Duffy JE (2003) Biodiversity loss, trophic skew and ecosystem functioning. Ecol Lett 6:680-687

Duffy JE, Hay ME (2000) Strong impacts of grazing amphipods on the organization of a benthic community. Ecol Monogr 70:237-263

Duffy JE, Richardson JP, Canuel EA (2003) Grazer diversity effects on ecosystem functioning in seagrass beds. Ecol Lett 6:637-645

Duffy JE, Richardson JP, France KE (2005) Ecosystem consequences of diversity depend on food chain length in estuarine vegetation. Ecol Lett 8:301-309

Forrester GE, Dudley TL, Grimm NB (1999) Trophic interactions in open systems: effects of predators and nutrients on stream food chains. Limnol Oceanogr 44:1187-1197

Hansen LS, Blackburn TH (1992) Effect of algal bloom deposition on sediment respiration and fluxes. Mar Biol 112: $147-152$

> Harvey HR (1994) Fatty acids and sterols as source markers of organic matter in sediments of the North Carolina continental slope. Deep-Sea Res II Top Stud Oceanogr 41: 783-796

Harwood JL, Russell NJ (1984) Lipids in plants and microbes. George Allen \& Unwin, Boston

Heck KL Jr, Valentine JF (2006) Plant-herbivore interactions in seagrass meadows. J Exp Mar Biol Ecol 330:420-436

Heck KL, Valentine JF (2007) The primacy of top-down 
effects in shallow benthic ecosystems. Estuaries Coasts 30: 371-381

Heck KL, Pennock JR, Valentine JF, Coen LD, Sklenar SA (2000) Effects of nutrient enrichment and small predator density on seagrass ecosystems: an experimental assessment. Limnol Oceanogr 45:1041-1057

Hedges JI, Stern JH (1984) Carbon and nitrogen determinations of carbonate-containing solids. Limnol Oceanogr 29: 657-663

Hemminga MA (1998) The root/rhizome system of seagrasses: an asset and a burden. J Sea Res 39:183-196

Hillebrand H (2002) Top-down versus bottom-up control of autotrophic biomass - a meta-analysis on experiments with periphyton. J N Am Benthol Soc 21:349-369

Hughes AR, Bando KJ, Rodriguez LF, Williams SL (2004) Relative effects of grazers and nutrients on seagrasses: a meta-analysis approach. Mar Ecol Prog Ser 282:87-99

Jernakoff P, Nielsen J (1997) The relative importance of amphipod and gastropod grazers in Posidonia sinuosa meadows. Aquat Bot 56:183-202

Knepel K, Bogren K (2002) Determination of orthophosphate by flow injection analysis. In: QuikChem method. Lachat Instruments, Milwaukee, WI, p 31-115-101-111-H

Lechevalier HA, Lechevalier MP (1988) Chemotaxonomic use of lipids - an overview. In: Ratledge C, Wilkinson SG (eds) Microbial lipids, Vol 1. Academic Press, London, p 869-902

Liao N (2002) Determination of ammonia in brackish or seawater by flow injection analysis. In: QuikChem method. Lachat Instruments, Milwaukee, WI, p 31-107-106-101-B

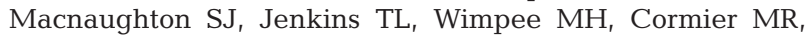
White DC (1997) Rapid extraction of lipid biomarkers from pure culture and environmental samples using pressurized accelerated hot solvent extraction. J Microbiol Methods 31:19-27

Meyers PA (1997) Organic geochemical proxies of paleoceanographic, paleolimnologic, and paleoclimatic processes. Org Geochem 27:213-250

Napolitano GE (1998) Fatty acids as trophic and chemical markers in freshwater ecosystems. In: Arts MT, Wainman BC (eds) Lipids in freshwater ecosystems. Springer, New York, p 21-44

Neubauer SC, Miller WD, Anderson IC (2000) Carbon cycling in a tidal freshwater marsh ecosystem: a carbon gas flux study. Mar Ecol Prog Ser 199:13-30

Oksanen L, Fretwell SD, Arruda J, Niemela P (1981) Exploitation ecosystems in gradients of primary productivity. Am Nat 118:240-261

Editorial responsibility: Morten Pedersen, Roskilde, Denmark
Orth RJ, Carruthers TJB, Dennison WC, Duarte CM and others (2006) A global crisis for seagrass ecosystems. Bioscience 56:987-996

Pace ML, Cole JJ, Carpenter SR, Kitchell JF (1999) Trophic cascades revealed in diverse ecosystems. Trends Ecol Evol $14: 483-488$

Perez M, Invers O, Ruiz JM, Frederiksen MS, Holmer M (2007) Physiological responses of the seagrass Posidonia oceanica to elevated organic matter content in sediments: an experimental assessment. J Exp Mar Biol Ecol 344: $149-160$

Pergent G, Romero J, Pergentmartini C, Mateo MA, Boudouresque CF (1994) Primary production, stocks and fluxes in the Mediterranean seagrass Posidonia oceanica. Mar Ecol Prog Ser 106:139-146

Shin KH, Hama T, Yoshie N, Noriki S, Tsunogai S (2000) Dynamics of fatty acids in newly biosynthesized phytoplankton cells and seston during a spring bloom off the west coast of Hokkaido Island, Japan. Mar Chem 70:243-256

Smith P, Bogren K (2001) Determination of nitrate and/or nitrite in brackish or seawater by flow injection analysis colorimetry. In: QuikChem method. Lachat Instruments, Milwaukee, WI, p 31-107-104-101-E

Spivak AC, Canuel EA, Duffy JE, Richardson JP (2007) Topdown and bottom-up controls on sediment organic matter composition in an experimental seagrass ecosystem. Limnol Oceanogr 52:2595-2607

Taylor J, Parkes RJ (1985) Identifying different populations of sulfate-reducing bacteria within marine sediment systems, using fatty-acid biomarkers. J Gen Microbiol 131: $631-642$

Valentine JF, Duffy JE (2006) The central role of grazing in seagrass ecology. In: Larkum AWD, Orth RJ, Duarte CM (eds) Seagrasses: biology, ecology, and conservation. Springer, Dordrecht, $\mathrm{p}$ 463-501

> Viso AC, Marty JC (1993) Fatty acids from 28 marine microalgae. Phytochemistry 34:1521-1533

> Volkman JK, Barrett SM, Blackburn SI, Mansour MP, Sikes EL, Gelin F (1998) Microalgal biomarkers: a review of recent research developments. Org Geochem 29: 1163-1179

Zimmerman AR, Canuel EA (2001) Bulk organic matter and lipid biomarker composition of Chesapeake Bay surficial sediments as indicators of environmental processes. Estuar Coast Shelf Sci 53:319-341

Zimmerman AR, Canuel EA (2002) Sediment geochemical records of eutrophication in the mesohaline Chesapeake Bay. Limnol Oceanogr 47:1084-1093

Submitted: December 23, 2007; Accepted: November 4, 2008 Proofs received from author(s): February 2, 2009 